\title{
Deriving Nickel (Ni(II)) and Chromium (Cr(III)) Based Environmentally Safe Olivine Guidelines for Coastal Enhanced Silicate Weathering
}

\author{
Gunter Flipkens, * Ronny Blust, and Raewyn M. Town
}

Cite This: Environ. Sci. Technol. 2021, 55, 12362-12371

Read Online

ABSTRACT: Enhanced silicate weathering (ESW) by spreading finely ground silicate rock along the coastal zone to remove atmospheric carbon dioxide $\left(\mathrm{CO}_{2}\right)$ is a proposed climate change mitigation technique. The abundant and fast-dissolving mineral olivine has received the most attention for this application. However, olivine contains nickel $(\mathrm{Ni})$ and chromium (Cr), which may pose a risk to marine biota during a gigaton-scale ESW application. Herein we derive a first guideline for coastal olivine dispersal based on existing marine environmental quality standards (EQS) for $\mathrm{Ni}$ and Cr. Results show that benthic biota are at the highest risk when olivine and its associated trace metals are mixed in the surface sediment. Specifically, depending on local sedimentary $\mathrm{Ni}$ concentrations, $0.059-1.4 \mathrm{~kg}$ of olivine

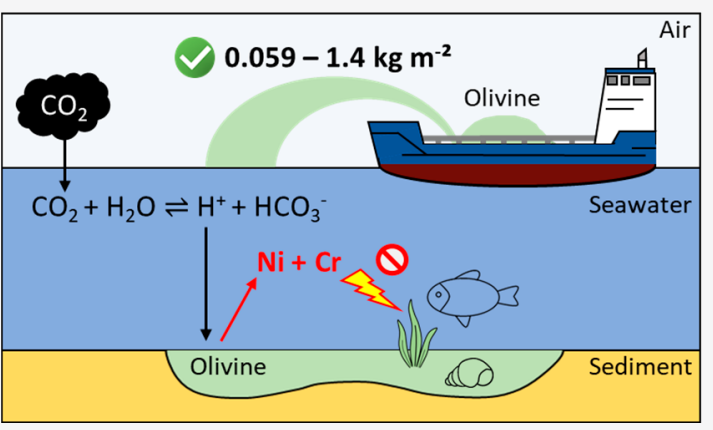
$\mathrm{m}^{-2}$ of seabed could be supplied without posing risks for benthic biota.

Accordingly, globally coastal ESW could safely sequester only $0.51-37 \mathrm{Gt}$ of $\mathrm{CO}_{2}$ in the 21 st century. On the basis of current EQS, we conclude that adverse environmental impacts from $\mathrm{Ni}$ and $\mathrm{Cr}$ release could reduce the applicability of olivine in coastal ESW. Our findings call for more in-depth studies on the potential toxicity of olivine toward benthic marine biota, especially in regard to bioavailability and metal mixture toxicity.

KEYWORDS: negative $\mathrm{CO}_{2}$ emissions, coastal enhanced silicate weathering, climate change mitigation, environmental risk assessment, nickel, chromium, olivine, ocean alkalinization

\section{INTRODUCTION}

Achieving the goals set in the 2015 Paris agreement to limit global warming to well below $2{ }^{\circ} \mathrm{C}$ will require drastic reductions in anthropogenic greenhouse gas emissions during the coming decades. ${ }^{1}$ Additionally, carbon dioxide $\left(\mathrm{CO}_{2}\right)$ will also need to be captured from the atmosphere by so-called negative emission technologies (NETs). ${ }^{2}$ These NETs are needed to be able to achieve net zero $\mathrm{CO}_{2}$ emissions by the year 2050 and net negative $\mathrm{CO}_{2}$ emissions during the second half of the 21st century. ${ }^{3,4}$ One of the proposed NETs is coastal enhanced silicate weathering (ESW). This technique aims to artificially speed up the natural $\mathrm{CO}_{2}$-consuming chemical weathering of a silicate mineral by supplying gigatons of finely ground source rock to the dynamic coastal environment. $^{5}$

The mineral olivine $\left(\mathrm{Mg}_{2 x} \mathrm{Fe}_{2(1-x)} \mathrm{SiO}_{4}\right)$ is a prime candidate for coastal ESW because of its relatively fast dissolution rate and widespread abundance. ${ }^{5-7}$ Billions of tonnes of olivine are globally present in mafic and ultramafic igneous rocks, and each year approximately $8 \mathrm{Mt}$ is mined from dunite (rock containing $>90 \%$ olivine) or serpentinite (metamorphosed olivine-rich ultramafic rock) deposits for metallurgical use. ${ }^{8-10}$ Relatively low energy costs and low $\mathrm{CO}_{2}$ emissions associated with grinding olivine source rock to $100 \mu \mathrm{m}$ particles make this a desirable grain size for use in coastal ESW. ${ }^{6}$ However, several studies indicate that grain sizes of $10 \mu \mathrm{m}$ or smaller might be needed to ensure significant olivine dissolution and $\mathrm{CO}_{2}$ uptake in the coming decades. $6,7,11$

During olivine dissolution, protons are consumed (eq 1), which leads to a shift in the equilibrium of the acid-base reactions of the seawater-carbonate system (eq 2) to the right. Consequently, seawater total alkalinity (TA) will increase, and additional $\mathrm{CO}_{2}$ can be taken up from the atmosphere (eq 3). ${ }^{5}$ This artificial seawater TA increase to drive atmospheric $\mathrm{CO}_{2}$ removal is called ocean alkalinization $(\mathrm{OA})$ or ocean alkalinity enhancement (OAE). ${ }^{12,13}$

$$
\begin{aligned}
& \mathrm{Mg}_{2 x} \mathrm{Fe}_{2(1-x)} \mathrm{SiO}_{4}+4 \mathrm{H}^{+} \\
& \quad \rightarrow 2 x \mathrm{Mg}^{2+}+2(1-x) \mathrm{Fe}^{2+}+\mathrm{H}_{4} \mathrm{SiO}_{4} \\
& \mathrm{CO}_{2}(\mathrm{aq})+\mathrm{H}_{2} \mathrm{O} \rightleftharpoons \mathrm{HCO}_{3}{ }^{-}+\mathrm{H}^{+} \rightleftharpoons \mathrm{CO}_{3}{ }^{2-}+2 \mathrm{H}^{+}
\end{aligned}
$$

Received: May 7, 2021

Revised: July 13, 2021

Accepted: August 4, 2021

Published: August 31, 2021 


$$
\mathrm{CO}_{2}(\mathrm{~atm}) \rightleftharpoons \mathrm{CO}_{2}(\mathrm{aq})
$$

Combining these reactions gives the overall dissolution reaction of olivine (eq 4), from which we can derive that theoretically $4 \mathrm{~mol}$ of $\mathrm{CO}_{2}$ is sequestered in the form of bicarbonate $\left(\mathrm{HCO}_{3}^{-}\right)$per mole of dissolved olivine. ${ }^{14}$

$$
\begin{aligned}
& \mathrm{Mg}_{2 x} \mathrm{Fe}_{2(1-x)} \mathrm{SiO}_{4}+4 \mathrm{H}_{2} \mathrm{O}+4 \mathrm{CO}_{2} \\
& \quad \rightarrow 2 x \mathrm{Mg}^{2+}+2(1-x) \mathrm{Fe}^{2+}+\mathrm{H}_{4} \mathrm{SiO}_{4}+4 \mathrm{HCO}_{3}^{-}
\end{aligned}
$$

In addition to $\mathrm{CO}_{2}$ sequestration, the proton consumption during dissolution could counteract ocean acidification. Furthermore, the released iron $(\mathrm{Fe})$ and silicon $(\mathrm{Si})$ are necessary nutrients for phytoplankton growth and could therefore result in additional atmospheric $\mathrm{CO}_{2}$ uptake and increased abundance of silicifiers (e.g., diatoms), but these aspects remain to be investigated. ${ }^{5,13}$ In contrast to these associated benefits, olivine also contains chromium $(\mathrm{Cr})$ and nickel $(\mathrm{Ni})$, which are toxic to marine organisms above certain threshold concentrations. ${ }^{5,15}$

Nickel is a transition metal that is mainly used in the production of stainless steel and other $\mathrm{Ni}$ alloys. ${ }^{16}$ In the crystal structure of olivine, $\mathrm{Ni}^{2+}$ is homogeneously distributed in the M1 octahedral binding sites, substituting for other divalent cations such as $\mathrm{Mg}^{2+}$ or $\mathrm{Fe}^{2+}$, thereby forming a nickel silicate $\left(\mathrm{Ni}_{2} \mathrm{SiO}_{4}\right){ }^{17,18}$ The $\mathrm{Ni}$ content in olivine ranges from 2.4 to $12 \mathrm{mmol}$ of $\mathrm{Ni} \mathrm{mol}^{-1}$ of olivine depending on the site of origin. ${ }^{14,18,19}$ Nickel is an essential component of nine enzymes associated with carbon, nitrogen, and oxygen cycling in marine microorganisms. ${ }^{20,21}$ However, for other marine biota $\mathrm{Ni}$ essentiality has not been recognized and the uptake mechanisms are not well-known. ${ }^{22}$ Exposure to elevated concentrations of $\mathrm{Ni}$ can lead to toxicological effects as a consequence of three main toxicity mechanisms: (1) ionoregulatory disruption (mainly $\mathrm{Ca}^{2+}, \mathrm{Mg}^{2+}$, and $\mathrm{Fe}^{2+/ 3+}$ ), (2) respiratory toxicity as a result of an allergic type reaction of respiratory epithelia, and (3) reactive oxygen species induced oxidative stress. ${ }^{16,22}$ However, the relative importance of the different toxicity mechanisms is not well-known for marine organisms. $^{22}$

In contrast to nickel, chromium is not homogeneously distributed in olivine, but rather is present in iron $(\mathrm{Fe})$-rich areas, likely as $\mathrm{Cr}^{3+}$ in the form of water-insoluble chromite $\left(\mathrm{FeCr}_{2} \mathrm{O}_{4}\right) \cdot{ }^{18}$ Reported $\mathrm{Cr}$ concentrations in olivine from the Norwegian Åheim mine (the largest exploited olivine source) vary considerably, ranging from $0.19 \mathrm{mmol} \mathrm{mol}^{-1}$ of olivine to $6.6 \mathrm{mmol} \mathrm{mol}^{-1}$ of olivine. ${ }^{14,18,19,23,24}$ In the marine environment $\mathrm{Cr}$ occurs in two stable oxidation states, $\mathrm{Cr}^{3+}$ and $\mathrm{Cr}^{6+}$, which differ significantly in their environmental and biological behaviors. ${ }^{25}$ Hexavalent $\mathrm{Cr}$ occurs as chromate $\left(\mathrm{CrO}_{4}{ }^{2-}\right)$ or dichromate $\left(\mathrm{Cr}_{2} \mathrm{O}_{7}{ }^{2-}\right)$ anions in aquatic systems, which can easily cross biological membranes via nonspecific anion channels and are therefore considered highly bioavailable and potentially very toxic. ${ }^{25-27}$ After entering the cell, $\mathrm{Cr}(\mathrm{VI})$ is reduced to $\mathrm{Cr}(\mathrm{III})$. This reduction is accompanied by the production of reactive oxygen species (ROS) which can damage cell membranes, proteins, and DNA when in excess of antioxidant molecules. ${ }^{27,28}$ By contrast, trivalent chromium is predominantly present as $\mathrm{Cr}(\mathrm{OH})_{3}$ or $\mathrm{Cr}(\mathrm{OH})_{2}{ }^{+}$in the marine environment, which are chemical species of less ecotoxico- logical concern compared to $\mathrm{Cr}(\mathrm{VI})$ species due to their low aqueous solubilities. $^{25,29}$

A body of literature is available on the acute and chronic toxicities of $\mathrm{Ni}^{2+}$ and $\mathrm{Cr}^{3+} / \mathrm{Cr}^{6+}$ toward marine biota. ${ }^{30-37}$ Most of the data have been derived from laboratory studies that exposed single biological species to single metal ions (e.g., $\mathrm{Ni}^{2+}$ or $\mathrm{Cr}^{3+}$ ) under optimal conditions (e.g., constant $\mathrm{pH}$ and temperature). With the use of various approaches, e.g., species sensitivity distributions (SSDs), these data are used to derive marine metal environmental quality standards (EQS), which are threshold metal concentrations in seawater or sediment that are considered to be sufficiently protective for the aquatic environment. $^{38}$ These EQS are used by industries, the government, and environmental agencies as a guidance tool in the setting of regulations. ${ }^{39}$

It has been predicted that, depending on the weathering rate and the water residence time, ESW may cause accumulation of $\mathrm{Cr}$ and $\mathrm{Ni}$ in coastal waters to levels that are well above the background. ${ }^{5,15}$ Currently, possible negative ecosystem impacts of coastal ESW are unknown since no marine toxicity tests have yet been conducted with olivine. However, for $\mathrm{Ni}$ and $\mathrm{Cr}$ considered individually, marine EQS do exist. Therefore, this study aimed to derive a maximum amount of olivine that could be supplied to the coastal seas without exceedance of the $\mathrm{Ni}$ or $\mathrm{Cr}$ EQS. This olivine guideline provides a first indication of the environmental safety and applicability of the mineral for employment in global-scale coastal ESW.

\section{MATERIALS AND METHODS}

All calculations were performed in Microsoft Excel (2016), and figures were constructed in GraphPad Prism version 9.01 for Windows (GraphPad Software, La Jolla, CA, USA).

Global Coastal Ni and $\mathrm{Cr}$ Concentrations. Data on $\mathrm{Ni}$ and $\mathrm{Cr}$ concentrations in coastal seawater and sediment were compiled from primary literature. Coastal waters were defined as those with a water depth up to $200 \mathrm{~m}$, located on continental or insular shelves. ${ }^{40}$ Data were included when the water depth at the sampling location was $\leq 200 \mathrm{~m}$ or when it was specified that the sampling was conducted in bays, lagoons, estuaries, near-shore banks, harbors, or coastal zones. ${ }^{40}$ For Ni and $\mathrm{Cr}$ in seawater, only data on dissolved metal concentrations (meaning water samples filtered through $\leq 0.45 \mu \mathrm{m}$ pore size filters) were collected. For sediment, metal concentrations on a dry weight (dry wt) basis measured after microwave-assisted acid mixture digestion of sieved or unsieved sediment were included. Data collected on a transect along a coastline (e.g., on a cruise or along an expected pollution gradient) or at different time points or depths on the same location were summarized using descriptive statistics (Tables S4-S7 and Figures S1-S4). The mean concentrations for each location were then summarized in the same way to derive median values and percentiles of $\mathrm{Ni}$ and $\mathrm{Cr}$ in a coastal environment around the globe.

Deriving a Ni-Based Guideline for Olivine Application in Coastal Systems. The occurrence of most $\mathrm{Cr}$ in olivine as water-insoluble $\mathrm{FeCr}_{2} \mathrm{O}_{4}$ implies low bioavailability and lower ecotoxicological concern compared to $\mathrm{Ni}^{18}$ Therefore, the following calculations were made under the assumption that $\mathrm{Ni}$ release from olivine weathering is the factor of highest concern for the health of marine biota during a gigaton-scale olivine application in the world's coastal seas. ${ }^{5,7}$ The corresponding calculations for $\mathrm{Cr}$ are given and discussed in the Supporting Information. 
On the basis of the environmental quality standards for $\mathrm{Ni}$ in marine water and sediment, the expected maximum amount of olivine that could be supplied to the coastal zone without adverse effects for marine biota was calculated. Calculations were made assuming the two limiting application scenarios where that all metals released during weathering end up in either the water column or the sediment.

All Ni Ends Up in the Water Column. The maximum amount of olivine, $m_{\mathrm{app}}$, that could be applied per square meter of seabed $\left(\mathrm{kg} \mathrm{m}^{-2}\right)$ without exceeding the Ni marine EQS was calculated from

$$
m_{\mathrm{app}}=\frac{c_{\mathrm{max}} V_{\mathrm{w}}}{k_{\mathrm{diss}} A t}
$$

where $c_{\max }$ is the maximum allowed concentration of olivine $\left(\mathrm{mol} \mathrm{L}^{-1}\right)$ based on the European seawater Ni EQS $(0.147$ $\left.\mu \mathrm{mol} \mathrm{L}{ }^{-1}\right),{ }^{41} V_{\mathrm{w}}$ is the water volume per square meter of seabed $\left(\mathrm{L} \mathrm{m}^{-2}\right), A$ is the reactive surface area of olivine $\left(\mathrm{m}^{2}\right.$ $\left.\mathrm{kg}^{-1}\right), t$ is the water residence time $(\mathrm{s})$, and $k_{\text {diss }}$ is the olivine dissolution rate constant $\left(\mathrm{mol} \mathrm{m} \mathrm{m}^{-2}\right)$. The dissolution of olivine was modeled for two grain sizes, 100 and $10 \mu \mathrm{m}$ grain diameters, for both temperate $\left(15^{\circ} \mathrm{C}\right)$ and tropical $\left(25^{\circ} \mathrm{C}\right)$ coastal systems. For all further calculations, the dissolution rate constants for olivine were considered to be $5.19 \times 10^{-11}$ and $1.58 \times 10^{-10} \mathrm{~mol} \mathrm{~m}^{-2} \mathrm{~s}^{-1}$ for the 15 and $25^{\circ} \mathrm{C}$ scenarios, respectively as derived by Hangx and Spiers. ${ }^{6}$ A more detailed description of how seawater Ni EQS based olivine guidelines were derived is provided in the Supporting Information.

All Ni Remains in the Sediment. For sediment, the maximum amount of olivine, $m_{\text {app }}$, that could be supplied per square meter of seabed $\left(\mathrm{kg} \mathrm{m}^{-2}\right)$ without exceeding the marine Ni EQS for sediment was calculated from

$$
m_{\mathrm{app}}=C_{\max } V_{\mathrm{s}} \rho_{\mathrm{s}}(1-\Phi) M_{\text {olivine }}
$$

where $C_{\max }$ is the maximum allowed amount of olivine ( $\mathrm{mmol}$ $\mathrm{kg}^{-1}$ dry wt) based on a sediment Ni EQS (0.729 mmol kg-1 dry wt), ${ }^{42} V_{\mathrm{s}}$ is the volume of the sediment in which olivine is mixed per square meter of seabed $\left(\mathrm{m}^{3} \mathrm{~m}^{-2}\right.$ seabed $), \rho_{\mathrm{s}}$ is the specific density of marine sediment $\left(2650 \mathrm{~kg} \mathrm{~m}^{-3}\right), M_{\text {olivine }}$ is the molecular weight of olivine $\left(\mathrm{kg} \mathrm{mol}^{-1}\right)$, and $\Phi$ is the porosity of the sediment. The application of common forsterite olivine with a molar Mg-to-Fe ratio of 0.94:0.06 $\left(\mathrm{Mg}_{1.88} \mathrm{Fe}_{0.12} \mathrm{SiO}_{4}\right)$ was assumed, resulting in a molecular weight of $0.144 \mathrm{~kg} \mathrm{~mol}^{-1} .^{14}$ The porosity of marine surface sediment was assumed to be 0.60 based on the predicted global coastal sediment porosity ranging from approximately 0.50 to $0.85 .^{43}$ To estimate the global maximum amount of olivine that could be distributed, the global continental shelf was assumed to have a surface area of $28 \times 10^{6} \mathrm{~km}^{2}$ for all further calculations. ${ }^{40}$

Implications of the Olivine Guideline for $\mathrm{CO}_{2}$ Sequestration Potential. Based on the derived olivine guideline value for coastal ESW, the associated $\mathrm{CO}_{2}$ uptake during the 21 st century was calculated to investigate if $\mathrm{Ni}$ release could limit the potential of coastal enhanced olivine weathering as an NET. Under the assumption that olivine grains are spherical, olivine is expected not to dissolve linearly over the coming decades, but to dissolve according to a shrinking core model. ${ }^{6}$ The volume fraction of dissolved olivine $X(t)$ at time $t$ can be expressed as

$$
X(t)=\frac{d_{0}{ }^{3}-\left(d_{0}-2 k_{\mathrm{diss}} V_{\mathrm{m}} t\right)^{3}}{d_{0}{ }^{3}}
$$

where $d_{0}$ is the starting olivine grain diameter $(\mathrm{m}) ; k_{\text {diss }}$ is the dissolution rate constant of olivine $\left(\mathrm{mol} \mathrm{m}^{-2} \mathrm{~s}^{-1}\right)$, and $V_{\mathrm{m}}$ is the molar volume of olivine $\left(4.38 \times 10^{-5} \mathrm{~m}^{3} \mathrm{~mol}^{-1}\right)$. The dissolution of olivine was modeled for two grain sizes, 100 and $10 \mu \mathrm{m}$ grain diameters, for both temperate $\left(15{ }^{\circ} \mathrm{C}\right)$ and tropical $\left(25^{\circ} \mathrm{C}\right)$ coastal systems. A weekly application of 9.615 Mt of olivine along the global continental shelf was assumed. This would equate to $500 \mathrm{Mt}$ of olivine spread along the coast every year, which was estimated to be logistically feasible by Hangx and Spiers ${ }^{6}$ assuming significant expansion of the cargo ship fleet size and olivine mining industry. The amount of olivine dissolved as a function of time is calculated from

$$
m_{\mathrm{oa}}=\sum_{t=0}^{n} X(t) S
$$

$$
\text { with } n=\text { duration of olivine application (weeks) }
$$

where $m_{\mathrm{oa}}$ is the amount of olivine (Mt) weathered at time $t$ (weeks), $X(t)$ is the fraction of olivine dissolved at time $t$ (weeks), and $S$ is the supply rate of olivine (9.615 $\mathrm{Mt} \mathrm{week}^{-1}$ ) for an $n$-week application. In a typical application scenario, the olivine supply will be stopped after $n$ weeks, i.e., once the global continental shelf has been covered in olivine and the expected maximum environmentally safe amount of olivine has been reached. The weekly amount of dissolved olivine for the next $4160-n$ weeks (i.e., after olivine application has stopped) can then be expressed as

$$
m_{\mathrm{os}}=\sum_{i=1}^{4160-n} \sum_{t=0}^{n} X(t+i) S
$$

with $n=$ duration of olivine application (weeks)

where $m_{\mathrm{os}}$ is the amount of olivine weathered (Mt) at time $t+i$ (weeks) from the moment olivine supply was halted onward, $i$ is the index for each week after olivine supply was stopped, $X(t$ $+i$ ) is the fraction of olivine dissolved at time $t+i$ (weeks), and $S$ is the supply rate of olivine (9.615 Mt week ${ }^{-1}$ ), for an $n$ week application. Subsequently, the associated weekly $\mathrm{CO}_{2}$ uptake was calculated from

$$
m_{\mathrm{CO}_{2}}=\gamma_{\mathrm{CO}_{2}} m_{\mathrm{oa} / \mathrm{os}}
$$

where $m_{\mathrm{CO}_{2}}$ is the amount of $\mathrm{CO}_{2}$ sequestered via olivine dissolution $(\mathrm{Mt}), \gamma_{\mathrm{CO}_{2}}$ is the net $\mathrm{CO}_{2}$-sequestration efficiency, which represents the net amount of $\mathrm{CO}_{2}$ that is withdrawn from the atmosphere upon dissolution of $1 \mathrm{~kg}$ of olivine, which was taken to be $1 \mathrm{~kg}$ of $\mathrm{CO}_{2}$ based on upper limits of expected values. ${ }^{5,14}$ Finally, $m_{\mathrm{oa} / \mathrm{os}}$ is the amount of olivine dissolved during the period of application $\left(m_{\mathrm{oa}}\right)$ or after the olivine supply was stopped $\left(m_{\mathrm{os}}\right)$, respectively.

\section{RESULTS AND DISCUSSION}

Global Coastal Ni Concentrations. A literature search was conducted to obtain globally occurring coastal $\mathrm{Ni}$ and $\mathrm{Cr}$ concentrations for the derivation of an olivine application guideline. A summary of the $\mathrm{Ni}$ concentrations globally occurring in coastal waters and sediment is shown in Table 1. A summary for $\mathrm{Cr}$ and data from individual studies are shown in Tables S1 and S4-S7 and Figures S1-S4. The 
Table 1. Summary of Dissolved ( $\leq 0.45 \mu \mathrm{m})$ Nickel (Ni) Concentrations $\left(\mathrm{nmol} \mathrm{L}^{-1}\right)$ in Seawater and Total Ni Concentrations ( $\mathrm{mmol} \mathrm{kg}^{-1}$ dry wt) in Sediment for Coastal Systems (Water Depth $\leq 200 \mathrm{~m}$ ) around the World ${ }^{a}$

$\begin{array}{lcc} & \begin{array}{c}\text { dissolved seawater }[\mathrm{Ni}] \\ \left.(\mathrm{nmol} \mathrm{L})^{-1}\right)\end{array} & \begin{array}{c}\text { total sediment }[\mathrm{Ni}] \\ \left(\mathrm{mmol} \mathrm{kg}^{-1} \mathrm{dry} \mathrm{wt}\right)\end{array} \\ \text { median } & (n=30) & (n=50) \\ \text { P25-P75 } & 3.92 & 0.52 \\ \text { P5-P95 } & 2.81-36.2 & 0.29-0.70 \\ \text { min-max } & 1.24-373 & 0.14-3.46 \\ \end{array}$

${ }^{a}$ Number of locations $(n)$, median, percentiles (P), and range (min$\max$ ) are provided to illustrate the distribution of the data. Results for $\mathrm{Cr}$ and mean data of the individual locations are provided in Tables S1 and S4-S7.

median dissolved $\mathrm{Ni}$ concentration in seawater for the 30 coastal locations was $3.92 \mathrm{nmol} \mathrm{L}^{-1}$. This value is similar to the reported dissolved $\mathrm{Ni}$ concentration in open ocean seawater of the Southern Ocean $\left.(6.2 \pm 0.3 \mathrm{nmol} \mathrm{L})^{-1}\right)^{44}$ and total $\mathrm{Ni}$ concentrations offshore in the Northeast Atlantic Ocean (3.9 $\left.\pm 1.6 \mathrm{nmol} \mathrm{L}^{-1}\right) .^{45}$ Dissolved $\mathrm{Ni}$ concentrations ranged from $0.92 \mathrm{nmol} \mathrm{L}^{-1}$ in 2002 in the Bay of Bengal in India to 5290 nmol L ${ }^{-1}$ in 2003 at the Alang-Sosiya ship scrapping yard in the Gulf of Cambay, India. ${ }^{46,47}$ Generally, human-impacted coastal waters and sediments tend to have elevated and more variable $\mathrm{Ni}$ concentrations than offshore locations due to nearshore mining or industrial activities. ${ }^{48,49}$

Total recoverable $\mathrm{Ni}$ concentrations in 50 coastal sediments ranged from $0.06 \mathrm{mmol} \mathrm{kg}^{-1}$ dry wt measured along the eastern Gulf of Mexico, USA, ${ }^{50}$ to $5.44 \mathrm{mmol} \mathrm{kg}^{-1}$ dry wt around the thermal power plant on the Tuticorin coast in India. ${ }^{51}$ The median sediment $\mathrm{Ni}$ concentration was 0.52 mmol kg${ }^{-1}$ dry wt. These concentrations are a lot higher than concentrations in water, showing that the sediment serves as a sink for metals in the marine environment. ${ }^{52}$

Deriving a Ni-Based Guideline for Olivine Application in Coastal Systems. The expected maximum amount of olivine that can be supplied to the coastal zone without exceedance of existing marine Ni EQS was derived for the two limiting olivine application scenarios in which all $\mathrm{Ni}$ released during olivine weathering ends up in either the water column or the sediment.

All Ni Ends Up in the Water Column. The maximum amount of olivine that can be distributed in coastal waters without exceedance of the European Ni EQS for seawater $(0.147 \mu \mathrm{M})^{41}$ assuming an olivine $\mathrm{Ni}$ concentration of 7.5 mmol mol ${ }^{-1}$ of olivine is shown in Figure 1. A seawater $\mathrm{Ni}$ background concentration of $3.92 \mathrm{nmol} \mathrm{L}{ }^{-1}$ was considered. As indicated by the study of Hangx and Spiers, ${ }^{6}$ based on the Arrhenius equation and an olivine dissolution activation energy of $79.5 \mathrm{~kJ} \mathrm{~mol}^{-1}$ in seawater conditions, ${ }^{53}$ the dissolution rate of olivine is expected to be approximately 3 times higher in

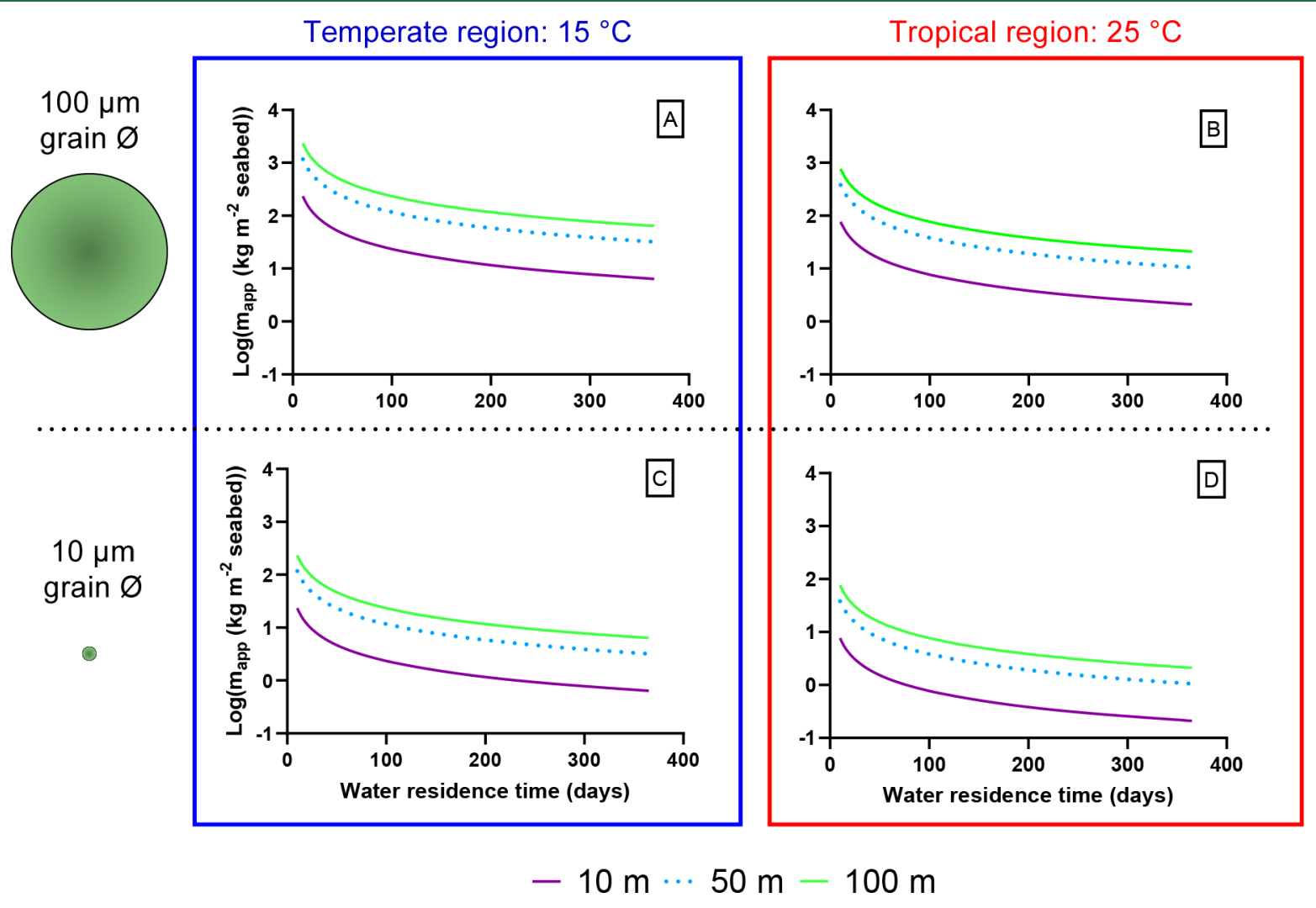

Figure 1. Maximum amount of olivine $\left(\mathrm{kg} \mathrm{m}^{-2}\right.$ seabed) on a logarithmic scale that can be distributed without exceedance of the European nickel $(\mathrm{Ni})$ environmental quality standard $(0.147 \mu \mathrm{M})$ as a function of coastal water residence time (days). Scenarios for coastal waters with an average water depth of 10,50 , or $100 \mathrm{~m}$ located in a $15{ }^{\circ} \mathrm{C}$ temperate region $(\mathrm{A}, \mathrm{C})$ or a $25^{\circ} \mathrm{C}$ tropical region (B, D) are shown. The maximum application of olivine with a uniform grain diameter of $100(\mathrm{~A}, \mathrm{~B})$ or $10 \mu \mathrm{m}(\mathrm{C}, \mathrm{D})$ is given. A seawater Ni background concentration of $3.92 \mathrm{nmol} \mathrm{L}{ }^{-1}$ and a $\mathrm{Ni}$ concentration in olivine of $7.5 \mathrm{mmol} \mathrm{mol}^{-1}$ of olivine were assumed. As derived by Hangx and Spiers, ${ }^{6}$ olivine dissolution rate constants of 5.19 $\times 10^{-11}$ and $1.58 \times 10^{-10} \mathrm{~mol} \mathrm{~m}{ }^{-2} \mathrm{~s}^{-1}$ were used for the temperate $\left(15^{\circ} \mathrm{C}\right)$ and tropical $\left(25^{\circ} \mathrm{C}\right)$ scenarios, respectively. 

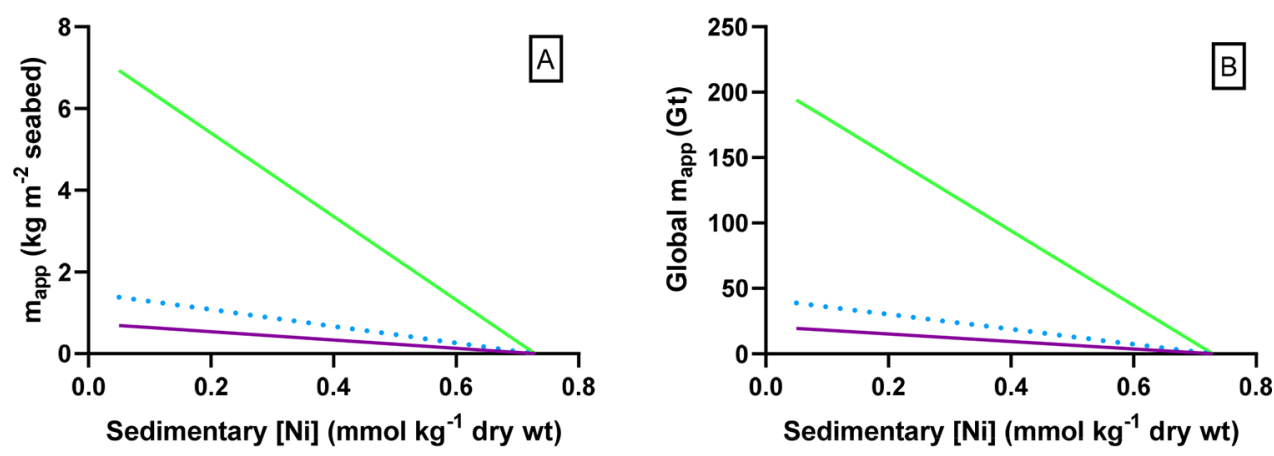

$-0.05 \mathrm{~m} \cdots 0.1 \mathrm{~m}-0.5 \mathrm{~m}$

Figure 2. Maximum amount of olivine, $m_{\text {app }}$, that can locally (A) or globally (B) be distributed without exceedance of the nickel (Ni) probable effect level (PEL) for marine biota $\left(0.729 \mathrm{mmol} \mathrm{kg}^{-1}\right.$ dry wt) as a function of sedimentary Ni concentrations ( $\left.\mathrm{mmol} \mathrm{kg}^{-1} \mathrm{dry} \mathrm{wt}\right)$ for different olivine mixing depths $\left(0.05,0.1\right.$, and $0.5 \mathrm{~m}$ ). The global continental shelf was assumed to have a surface area of $28 \times 10^{6} \mathrm{~km}^{2}$, and the olivine was assumed to have a nickel concentration of $7.5 \mathrm{mmol}$ of $\mathrm{Ni} \mathrm{mol}^{-1}$ of olivine. The worst-case scenario is shown for which all the nickel released from olivine weathering is assumed to stay inside the sediment.

tropical $\left(25{ }^{\circ} \mathrm{C}\right)$ compared to temperate $\left(15^{\circ} \mathrm{C}\right)$ coastal waters. ${ }^{6}$ Furthermore, assuming that the olivine grains are spherical, grains with a diameter of $10 \mu \mathrm{m}$ are expected to dissolve approximately 10 times faster than grains with a diameter of $100 \mu \mathrm{m}$ according to basic geometry (see eq 4 in the Supporting Information). ${ }^{6}$ If all Ni released during olivine weathering is being homogeneously mixed in the overlying water, then $\mathrm{Ni}$ concentrations will be 10 times lower at a location with a water depth of $100 \mathrm{~m}$ compared to a location with a $10 \mathrm{~m}$ water depth with the same water residence time.

From these assumptions, we can derive that for continental shelf seas with a short water residence time of 2 weeks, such as the East Brazil shelf in the South Atlantic Ocean or the California Current in the Pacific Ocean, ${ }^{54}$ relatively high quantities of olivine (on the order of $5-1.7 \times 10^{3} \mathrm{~kg} \mathrm{~m}^{-2}$ depending on water depth, temperature, and olivine grain size) can be distributed without exceedance of the European $\mathrm{Ni}$ EQS. For coastal waters with a relatively long residence time of approximately 1 year, such as the North Sea or the East China Sea, ${ }^{54}$ the amount of olivine that can be distributed is approximately 26 times lower than that for seas with a residence time of 2 weeks assuming total coverage of the continental shelf with olivine.

We note that these results were derived from average, laboratory-based olivine dissolution rate constants for seawater. ${ }^{6}$ However, when supplied to the coastal zone, the rate and extent of olivine dissolution could be enhanced or reduced by several biotic (e.g., bioturbation) and abiotic (e.g., wave induced pore water flushing or burial by sediment) processes. ${ }^{5}$ Furthermore, in deeper parts of continental shelf seas, released trace metals might not be homogeneously mixed in the water column due to the presence of seasonal or permanent pycnoclines (boundaries between two water layers of different density) or other oceanic processes. ${ }^{55}$ Moreover, an olivine $\mathrm{Ni}$ concentration of $7.5 \mathrm{mmol} \mathrm{mol}^{-1}$ of olivine was assumed, ${ }^{14}$ while concentrations can vary from 2.4 to $12 \mathrm{mmol}$ of $\mathrm{Ni}$ $\mathrm{mol}^{-1}$ of olivine depending on the origin of the source rock. ${ }^{18}$ Additionally, a low Ni background concentration $(3.92 \mathrm{nmol}$ $\mathrm{L}^{-1}$ ) was considered, while concentrations of up to 3 orders of magnitude higher have been observed. ${ }^{46}$ Finally, the European seawater Ni EQS of $0.147 \mu \mathrm{mol} \mathrm{L}^{-1}$ was used to derive the olivine guideline, but different EQS values are implemented in other regions (see Table S2) and $\mathrm{Ni}$ concentrations as low as
$0.102 \mu \mathrm{mol} \mathrm{L}{ }^{-1}$ have been recently recommended to ensure protection of marine biota. ${ }^{56}$

These sources of variation can significantly affect the olivine application guideline and should therefore be taken into account in the best way possible on a local scale when determining the amount of olivine that can be supplied to a specific coastal area. Especially the in situ olivine dissolution and metal release rate remain unknown and require additional research efforts. ${ }^{5}$

All Ni Ends Up in the Sediment. In addition to Ni EQS for seawater, there are also sediment Ni EQS values, of which the threshold effect level (TEL) and probable effect level (PEL) derived by the Florida Department of Environmental Protection (FDEP) (Table S3) are among the most widely used. $^{42,57}$ The TEL was derived to represent the pollutant concentration below which adverse biological effects rarely occur, while the PEL corresponds to the pollutant concentrations above which adverse biological effects are frequently expected. In the context of coastal ESW, a conservative approach would be to halt olivine deposition when future $\mathrm{Ni}$ release is expected to exceed the TEL. ${ }^{42,57}$ However, $76 \%$ of the collected coastal sedimentary $\mathrm{Ni}$ concentrations are above the TEL of $0.271 \mathrm{mmol}$ of $\mathrm{Ni} \mathrm{kg}^{-1}$ dry wt. Furthermore, in the biological effects database for sediments (BEDS), adverse biological effects were only observed in $9.4 \%$ of cases where sedimentary $\mathrm{Ni}$ concentrations exceeded the PEL, whereas for other metals these percentages were much higher (e.g., 56\% for copper). ${ }^{42}$ Moreover, Chapman et al. and Bakke et al. derived sediment Ni EQS at which biological effects were unlikely of 0.68 and $0.78 \mathrm{mmol} \mathrm{kg}^{-1}$ dry wt, respectively. ${ }^{58,59}$ Therefore, the PEL of $0.729 \mathrm{mmol} \mathrm{Ni} \mathrm{kg}^{-1}$ dry wt is a more suitable threshold concentration for deriving an olivine application guideline.

The maximum amount of olivine that can be distributed in coastal waters without future exceedance of the PEL derived for Florida coastal sediments $\left(0.729 \mathrm{mmol} \mathrm{kg}^{-1}\right.$ dry wt $)$ is shown in Figure 2. For the scenario where olivine remains in the upper $5 \mathrm{~cm}$ of the sediment, a maximum amount of $0.69 \mathrm{~kg}$ $\mathrm{m}^{-2}$ and minimum amount of $0.029 \mathrm{~kg} \mathrm{~m}^{-2}$ seabed can be dispersed without exceedance of the PEL if sedimentary $\mathrm{Ni}$ concentrations are 0.05 and $0.7 \mathrm{mmol}$ of $\mathrm{Ni} \mathrm{kg}{ }^{-1}$ dry wt, respectively (Figure 2A). In case the olivine gets mixed to greater depths by wave action or bioturbation in a site with an 
Temperate region: $15^{\circ} \mathrm{C}$

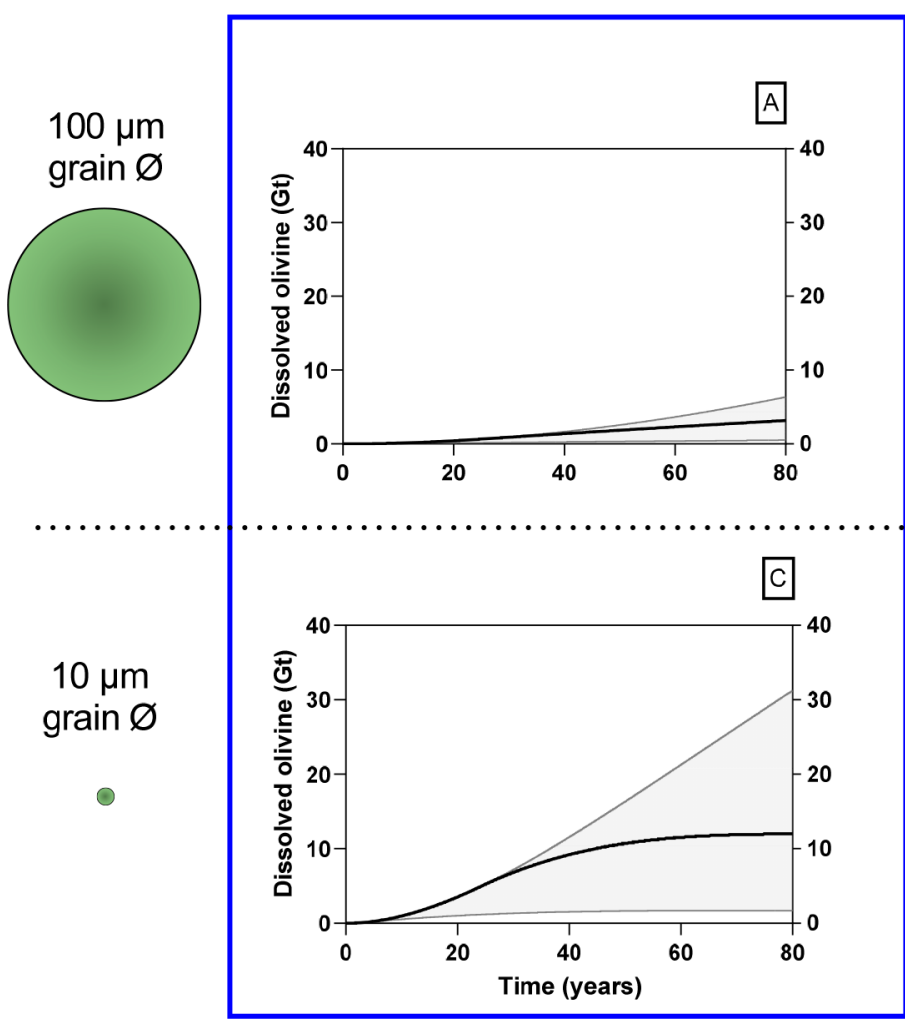

Tropical region: $25^{\circ} \mathrm{C}$

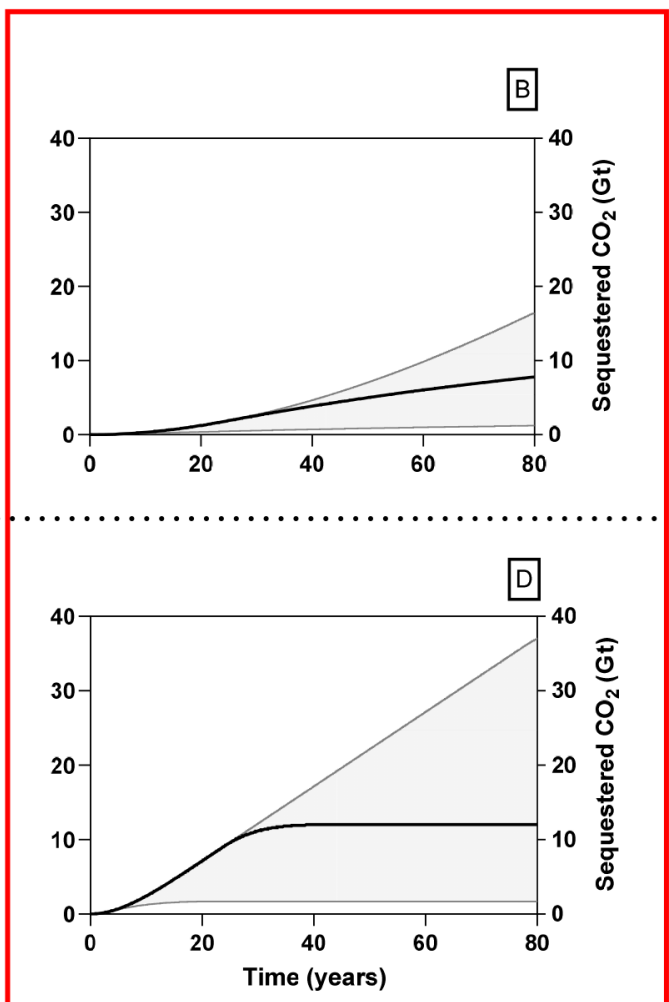

Figure 3. Amount of dissolved olivine (Gt) and associated $\mathrm{CO}_{2}$ sequestration $(\mathrm{Gt}$ ) as a function of time (years) for a 1.7-39 Gt global coastal enhanced olivine weathering scenario. A constant olivine supply rate $(S)$ of $9.615 \mathrm{Mt}^{-1} \mathrm{wek}^{-1}$ for a period of 3.4-78 years was assumed based on a sedimentary $\mathrm{Ni}$ concentration of $0.05-0.7 \mathrm{mmol} \mathrm{kg}{ }^{-1}$ dry wt. The solid black line shows the scenario where 12 Gt of olivine is supplied to an average coastal sediment $\left(0.52 \mathrm{mmol}\right.$ of $\mathrm{Ni} \mathrm{kg}^{-1}$ dry wt) for a period of 24 years. Scenarios for a $15{ }^{\circ} \mathrm{C}$ temperate region $(\mathrm{A}, \mathrm{C})$ and a $25{ }^{\circ} \mathrm{C}$ tropical region (B, D) are shown for olivine with a uniform grain diameter of $100(\mathrm{~A}, \mathrm{~B})$ or $10 \mu \mathrm{m}(\mathrm{C}, \mathrm{D})$. Olivine dissolution was assumed to occur according to a shrinking core model with olivine dissolution rate constants of $5.19 \times 10^{-11}$ and $1.58 \times 10^{-10} \mathrm{~mol} \mathrm{~m}^{-2} \mathrm{~s}^{-1}$ and an activation energy of $79.5 \mathrm{~kJ} \mathrm{~mol}^{-153}$ for the 15 and $25{ }^{\circ} \mathrm{C}$ scenarios, respectively. The $\mathrm{CO}_{2}$-sequestration efficiency was taken to be 1 ton of $\mathrm{CO}_{2}$ sequestered for each ton of dispersed olivine.

average sedimentary $\mathrm{Ni}$ concentration of $0.52 \mathrm{mmol}$ of $\mathrm{Ni} \mathrm{kg}^{-1}$ dry wt, double $\left(0.42 \mathrm{~kg} \mathrm{~m}^{-2}\right)$ or 10 times $\left(2.1 \mathrm{~kg} \mathrm{~m}^{-2}\right)$ the amount of olivine can be spread out on the seafloor for a 10 or $50 \mathrm{~cm}$ mixing depth scenario (Figure 2A).

Importantly, in these calculations the sediment Ni EQS derived for Florida waters were used while guidelines for a range of locations have been derived in the past $\sim 30$ years ranging from 0.27 to $0.75 \mathrm{mmol} \mathrm{kg}{ }^{-1}$ dry wt to protect local marine biota. ${ }^{60}$ Furthermore, marine sediments were considered a static sink for metals, while in reality metals are constantly exchanged between the sediment and the overlying water column. ${ }^{61}$ Metal efflux from the sediment is mainly driven by molecular diffusion, but it can be significantly enhanced by bioturbation and advection. ${ }^{61-63}$ To take these metal effluxes into consideration when deriving an olivine application guideline, accurate data on local biological and physicochemical processes in the sediment would be required. However, in the literature these data are scarce and can show significant temporal and spatial variations. ${ }^{61,64}$ Furthermore, the olivine mixing depth and weathering rate as a function of sediment depth and time need to be well-defined, since they would have a large effect on the magnitude of the metal influx and efflux. Currently these data are lacking. ${ }^{5}$ Therefore, olivine sediment EQS based guidelines were only derived under the conservative assumption that all trace metals released during olivine weathering remain in the sediment.
Collectively, the calculations show that benthic marine biota are at highest risk from $\mathrm{Ni}$ release during a large-scale coastal olivine application in the case where all the released $\mathrm{Ni}$ stays in the sediment. Assuming a mixing depth of $10 \mathrm{~cm}$ and a sedimentary Ni concentration of $0.52 \mathrm{mmol} \mathrm{kg}^{-1}$ dry wt, the maximum amount of olivine that can be distributed without future exceedance of the $\mathrm{Ni}$ guidelines is $0.42 \mathrm{~kg} \mathrm{~m}^{-2}$. When comparing this amount to the amount needed to surpass the $\mathrm{Ni}$ water quality guidelines, only in the case where very finegrained olivine (10 $\mu \mathrm{m}$ grain diameter) is dispersed in tropical $\left(25{ }^{\circ} \mathrm{C}\right)$ or shallow temperate $\left(15{ }^{\circ} \mathrm{C}, 10 \mathrm{~m}\right.$ water depth) coastal areas with a water residence time of more than half a year (>181 days), Ni water quality guidelines can be exceeded by dispersing lower amounts of olivine (Figure 1D). Therefore, for most locations around the world the maximum amount of olivine that can be dispersed should be based on the local sedimentary Ni concentrations.

Implications of the Olivine Guideline for $\mathrm{CO}_{2}$ Sequestration Potential. To investigate the potential of coastal ESW as an NET in the 21st century, the dissolution of an environmentally safe amount of olivine derived from the FDEP sediment Ni EQS and associated $\mathrm{CO}_{2}$ sequestration are shown in Figure 3. A $\mathrm{CO}_{2}$-sequestration efficiency of 1 ton of $\mathrm{CO}_{2}$ /ton of supplied olivine was assumed. ${ }^{14} \mathrm{~A}$ conservative environmentally safe olivine application of 1.7-39 Gt, spread over a period of 3.4-78 years, was calculated based on an 
olivine mixing depth of $10 \mathrm{~cm}$ and the assumption that all trace metals released during weathering remain in the sediment (Figure 2B). This mixing depth was based on the zone in the sediment where most benthic fauna is present. ${ }^{64,65}$ For the larger $100 \mu \mathrm{m}$ olivine grains, $0.51(\sim 30 \%)$ to $6.4 \mathrm{Gt}(\sim 16 \%)$ of the supplied olivine would have dissolved by the end of the 21 st century in a temperate $\left(15^{\circ} \mathrm{C}\right)$ region (Figure $\left.3 \mathrm{~A}\right)$ and $1.2(\sim 71 \%)$ to $16 \mathrm{Gt}(\sim 42 \%)$ would have dissolved in a tropical $\left(25^{\circ} \mathrm{C}\right)$ region (Figure $\left.3 \mathrm{~B}\right)$. Alternatively, if $10 \mu \mathrm{m}$ grain size olivine would be distributed, $1.7(100 \%)$ to $31 \mathrm{Gt}$ $(\sim 80 \%)$ and $1.7(100 \%)$ to $37 \mathrm{Gt}(\sim 95 \%)$ of the supplied olivine would be dissolved at the end of the 21st century for temperate and tropical zones, respectively (Figure 3C,D). These results highlight that olivine would have to be ground to very small grain sizes to dissolve fast enough to achieve significant $\mathrm{CO}_{2}$ withdrawal from the atmosphere during the coming decades. ${ }^{6,11}$

Based on the environmentally safe amount of olivine that could be applied to the global continental shelf, a maximum net amount of $\sim 0.51-37 \mathrm{Gt}$ of $\mathrm{CO}_{2}$ could be removed from the atmosphere during the 21 st century using coastal enhanced olivine weathering. Narrowing this result based on the median coastal sedimentary $\mathrm{Ni}$ concentration $\left(0.52 \mathrm{mmol} \mathrm{kg}^{-1}\right.$ dry wt), 3.2-12 Gt of $\mathrm{CO}_{2}$ could be sequestered in the coming 80 years depending on the olivine grain size, application location, and net $\mathrm{CO}_{2}$-sequestration efficiency. The latter is estimated to vary between 0.50 and 1.0 ton of $\mathrm{CO}_{2}$ sequestered per ton of dispersed olivine. ${ }^{5,66}$ The net $\mathrm{CO}_{2}$-sequestration efficiency is dependent on the mineral composition of the source rock, potential secondary mineral formation during olivine dissolution, and $\mathrm{CO}_{2}$ emissions from mining, grinding, and transportation of the olivine from its source to the coastal zone. $^{5,6,11,66}$

To keep global warming below $1.5{ }^{\circ} \mathrm{C}$, all NETs would need to collectively capture approximately $150-1180 \mathrm{Gt}$ of $\mathrm{CO}_{2}$ during the 21st century, depending on the rate of conventional mitigation. ${ }^{67}$ Therefore, a total $\mathrm{CO}_{2}$ capture potential of $0.51-$ $37 \mathrm{Gt}$ via coastal enhanced olivine weathering is relatively low. Hence, this first olivine application guideline shows that additional research on the environmental safety of the technique is needed.

Future Perspectives: The Need for Site-Specific Olivine Guidelines. Overall, our results show that $\mathrm{Ni}$ and $\mathrm{Cr}$ release could limit the potential safe usage of the mineral olivine in coastal enhanced silicate weathering on a global scale. As explained in more detail in the Supporting Information, the release of $\mathrm{Cr}$ is expected to be of lower concern compared to $\mathrm{Ni}$. However, the potential of some released $\mathrm{Cr}^{3+}$ to be oxidized to $\mathrm{Cr}^{6+}$, which forms anionic complexes in seawater that are highly bioavailable and potentially synergistically toxic with $\mathrm{Ni}^{2+}$, implies that $\mathrm{Cr}^{3+}$ release during olivine weathering cannot be disregarded in the risk assessment of coastal ESW. .5,27,29,68 $^{2}$

Ecological risk assessment of olivine in coastal ESW is still at a very early stage. Data on olivine toxicity in marine environments and accurate predictions on in situ olivine dissolution rates and mixing depths are still lacking. ${ }^{5}$ In a coastal environment, organisms will be exposed to $\mathrm{Ni}$ and $\mathrm{Cr}$ released in the water (porewater or overlying water) or in their gastrointestinal tracts after ingestion of sediment particles and/ or contaminated food. ${ }^{69}$ The degree of metal uptake will depend on the exposure concentration and duration, metal speciation, competition with other ions for uptake, abiotic variables (such as temperature, $\mathrm{pH}$, and organic carbon), and the organism's physiology. ${ }^{69,70}$ Toxicological effects will occur when metal concentrations in an organism's biologically active metal compartments exceed certain threshold values. ${ }^{69}$

Biotic ligand models (BLMs) have been used to account for site- and species-specific metal bioavailability in the derivation of the European freshwater Ni EQS and have been recently validated for Australian freshwater species. ${ }^{71,72}$ However, for marine systems additional research on the interactions between seawater chemistry, Ni bioavailability, and toxicity is needed to derive bioavailability based EQS. ${ }^{22,73}$

Differences in biogeochemical processes among coastal sites necessitate the derivation of site-specific olivine application guidelines. The risk assessment should be based on multiple lines of evidence (laboratory toxicity testing and field-based studies) to determine implications of coastal olivine spreading for ecosystem health. ${ }^{65}$ Potential benefits (counteracting ocean acidification and global warming) of olivine spreading should also be considered to decide how much olivine will ultimately be dispersed in a specific coastal sea. ${ }^{5}$

To conclude, we recommend that future studies try to fill in the data gap on olivine toxicity to marine biota and in situ olivine dissolution rates by (I) conducting laboratory flume experiments, (II) performing olivine toxicity tests for a range of (benthic) marine organisms (algae, invertebrates, and fish), and (III) conducting monitoring campaigns at natural olivine beaches (e.g., Papakōlea Beach, Hawaii) before starting largescale field trials. Our work provides a first conservative coastal olivine application guideline and highlights the need for additional research to perform an accurate site-specific risk assessment of coastal enhanced olivine weathering.

\section{ASSOCIATED CONTENT}

\section{Supporting Information}

The Supporting Information is available free of charge at https://pubs.acs.org/doi/10.1021/acs.est.1c02974.

More detailed description on how the olivine guidelines were derived based on seawater EQS for $\mathrm{Ni}$ and $\mathrm{Cr}$; globally occurring $\mathrm{Cr}$ concentrations in coastal seawater and sediment; literature data used to derive a summary on global coastal $\mathrm{Ni}$ and $\mathrm{Cr}$ concentrations; $\mathrm{Cr}$ EQS based olivine guidelines (PDF)

\section{AUTHOR INFORMATION}

\section{Corresponding Author}

Gunter Flipkens - Systemic Physiological and Ecotoxicological Research (SPHERE), Department of Biology, University of Antwerp, 2020 Antwerp, Belgium; (1) orcid.org/0000-00025645-4672; Email: Gunter.Flipkens@uantwerpen.be

\section{Authors}

Ronny Blust - Systemic Physiological and Ecotoxicological Research (SPHERE), Department of Biology, University of Antwerp, 2020 Antwerp, Belgium

Raewyn M. Town - Systemic Physiological and Ecotoxicological Research (SPHERE), Department of Biology, University of Antwerp, 2020 Antwerp, Belgium; (1) orcid.org/0000-0001-9505-1465

Complete contact information is available at: https://pubs.acs.org/10.1021/acs.est.1c02974 


\section{Notes}

The authors declare no competing financial interest.

\section{ACKNOWLEDGMENTS}

The authors would like to thank Filip J. R. Meysman, Luna Geerts, Géraldine Fiers, Laurine Burdorf, and the anonymous reviewers for their constructive comments on the manuscript. This study was financially supported by the Fonds voor Wetenschappelijk Onderzoek-Vlaanderen (FWO) SBO Project S000619N (Negative Emissions through Enhanced Mineral Weathering in the Coastal Zone).

\section{REFERENCES}

(1) Haszeldine, R. S.; Flude, S.; Johnson, G.; Scott, V. Negative emissions technologies and carbon capture and storage to achieve the Paris Agreement commitments. Philos. Trans. R. Soc., A 2018, 376 (2119), 20160447.

(2) Minx, J. C.; Lamb, W. F.; Callaghan, M. W.; Fuss, S.; Hilaire, J.; Creutzig, F.; Amann, T.; Beringer, T.; de Oliveira Garcia, W.; Hartmann, J.; et al. Negative emissions-Part 1: Research landscape and synthesis. Environ. Res. Lett. 2018, 13 (6), 063001.

(3) Detz, R. J.; van der Zwaan, B. Transitioning towards negative CO2 emissions. Energy Policy 2019, 133, 110938.

(4) Gasser, T.; Guivarch, C.; Tachiiri, K.; Jones, C.; Ciais, P. Negative emissions physically needed to keep global warming below 2 C. Nat. Commun. 2015, 6 (1), 7958.

(5) Meysman, F. J.; Montserrat, F. Negative CO2 emissions via enhanced silicate weathering in coastal environments. Biol. Lett. 2017, 13 (4), 20160905.

(6) Hangx, S. J.; Spiers, C. J. Coastal spreading of olivine to control atmospheric $\mathrm{CO} 2$ concentrations: A critical analysis of viability. Int. J. Greenhouse Gas Control 2009, 3 (6), 757-767.

(7) Hartmann, J.; West, A. J.; Renforth, P.; Köhler, P.; De La Rocha, C. L.; Wolf-Gladrow, D. A.; Dürr, H. H.; Scheffran, J. Enhanced chemical weathering as a geoengineering strategy to reduce atmospheric carbon dioxide, supply nutrients, and mitigate ocean acidification. Rev. Geophys. 2013, 51 (2), 113-149.

(8) Harben, P. W.; Smith, C., Jr. Olivine. In Industrial Minerals \& Rocks: Commodities, Markets, and Uses; Kogel, J. E., Trivedi, N. C., Barker, J. M., Krukowski, S. T., Eds.; Society for Mining, Metallurgy, and Exploration, Inc.: 2006; pp 679-683.

(9) Kremer, D.; Etzold, S.; Boldt, J.; Blaum, P.; Hahn, K. M.; Wotruba, H.; Telle, R. Geological mapping and characterization of possible primary input materials for the mineral sequestration of carbon dioxide in Europe. Minerals 2019, 9 (8), 485.

(10) Scott, A.; Oze, C.; Shah, V.; Yang, N.; Shanks, B.; Cheeseman, C.; Marshall, A.; Watson, M. Transformation of abundant magnesium silicate minerals for enhanced $\mathrm{CO} 2$ sequestration. Commun. Earth Environ. 2021, 2 (1), 25.

(11) Renforth, P. The potential of enhanced weathering in the UK. Int. J. Greenhouse Gas Control 2012, 10, 229-243.

(12) Ilyina, T.; Wolf-Gladrow, D.; Munhoven, G.; Heinze, C. Assessing the potential of calcium-based artificial ocean alkalinization to mitigate rising atmospheric $\mathrm{CO} 2$ and ocean acidification. Geophys. Res. Lett. 2013, 40 (22), 5909-5914.

(13) Bach, L. T.; Gill, S. J.; Rickaby, R. E.; Gore, S.; Renforth, P. $\mathrm{CO} 2$ removal with enhanced weathering and ocean alkalinity enhancement: Potential risks and co-benefits for marine pelagic ecosystems. Front. Clim. 2019, $1,7$.

(14) Montserrat, F.; Renforth, P.; Hartmann, J.; Leermakers, M.; Knops, P.; Meysman, F. J. Olivine dissolution in seawater: implications for $\mathrm{CO} 2$ sequestration through enhanced weathering in coastal environments. Environ. Sci. Technol. 2017, 51 (7), 3960-3972.

(15) Edwards, D. P.; Lim, F.; James, R. H.; Pearce, C. R.; Scholes, J.; Freckleton, R. P.; Beerling, D. J. Climate change mitigation: potential benefits and pitfalls of enhanced rock weathering in tropical agriculture. Biol. Lett. 2017, 13 (4), 20160715.
(16) Brix, K. V.; Schlekat, C. E.; Garman, E. R. The mechanisms of nickel toxicity in aquatic environments: An adverse outcome pathway analysis. Environ. Toxicol. Chem. 2017, 36 (5), 1128-1137.

(17) Bish, D. L. Cation ordering in synthetic and natural Ni-Mg olivine. Am. Mineral. 1981, 66 (7-8), 770-776.

(18) Santos, R. M.; Van Audenaerde, A.; Chiang, Y. W.; Iacobescu, R. I.; Knops, P.; Van Gerven, T. Nickel extraction from olivine: effect of carbonation pre-treatment. Metals 2015, 5 (3), 1620-1644.

(19) Keefner, J.; Mackwell, S.; Kohlstedt, D.; Heidelbach, F. Dependence of dislocation creep of dunite on oxygen fugacity: Implications for viscosity variations in Earth's mantle. J. Geophys. Res. 2011, 116 (B5), B05201.

(20) Ho, T.-Y. Nickel limitation of nitrogen fixation in Trichodesmium. Limnol. Oceanogr. 2013, 58 (1), 112-120.

(21) Mulrooney, S. B.; Hausinger, R. P. Nickel uptake and utilization by microorganisms. FEMS Microbiol. Rev. 2003, 27 (2-3), 239-261.

(22) Blewett, T. A.; Leonard, E. M. Mechanisms of nickel toxicity to fish and invertebrates in marine and estuarine waters. Environ. Pollut. 2017, 223, 311-322.

(23) Kleiv, R. A.; Thornhill, M. Dry magnetic separation of olivine sand. Physicochem. Probl. Miner. Process. 2011, 47, 213-228.

(24) Shur, M. Y.; Perchuk, A. Omphacite paradox in mantle peridotites. Russ Geol Geophys. 2015, 56 (11), 1568-1577.

(25) Aharchaou, I.; Py, J. S.; Cambier, S.; Loizeau, J. L.; Cornelis, G.; Rousselle, P.; Battaglia, E.; Vignati, D. A. Chromium hazard and risk assessment: New insights from a detailed speciation study in a standard test medium. Environ. Toxicol. Chem. 2018, 37 (4), 983992.

(26) Bakshi, A.; Panigrahi, A. A comprehensive review on chromium induced alterations in fresh water fishes. Toxicol. Rep. 2018, 5, 440447.

(27) Dayan, A.; Paine, A. Mechanisms of chromium toxicity, carcinogenicity and allergenicity: review of the literature from 1985 to 2000. Hum. Exp. Toxicol. 2001, 20 (9), 439-451.

(28) Wang, J. F.; Bashir, M.; Engelsberg, B. N.; Witmer, C.; Rozmiarek, H.; Billings, P. C. High mobility group proteins 1 and 2 recognize chromium-damaged DNA. Carcinogenesis. 1997, 18 (2), $371-375$.

(29) Pettine, M. Redox processes of chromium in sea water. In Chemical Processes in Marine Environments; Gianguzza, A., Pelizetti, E., Sammartano, S., Eds.; Springer: Berlin, 2000; pp 281-296.

(30) Gissi, F.; Stauber, J. L.; Binet, M. T.; Trenfield, M. A.; Van Dam, J. W.; Jolley, D. F. Assessing the chronic toxicity of nickel to a tropical marine gastropod and two crustaceans. Ecotoxicol. Environ. Saf. 2018, 159, 284-292.

(31) Bielmyer, G.; Brix, K.; Capo, T.; Grosell, M. The effects of metals on embryo-larval and adult life stages of the sea urchin, Diadema antillarum. Aquat. Toxicol. 2005, 74 (3), 254-263.

(32) Wang, Z.; Yeung, K. W.; Zhou, G.-J.; Yung, M. M.; Schlekat, C. E.; Garman, E. R.; Gissi, F.; Stauber, J. L.; Middleton, E. T.; Wang, Y. Y. L.; Leung, K. M. Y. Acute and chronic toxicity of nickel on freshwater and marine tropical aquatic organisms. Ecotoxicol. Environ. Saf. 2020, 206, 111373.

(33) Panneerselvam, K.; Marigoudar, S. R.; Dhandapani, M. Toxicity of Nickel on the Selected Species of Marine Diatoms and Copepods. Bull. Environ. Contam. Toxicol. 2018, 100 (3), 331-337.

(34) Urrutia, C.; Rudolph, A.; Lermanda, M. P.; Ahumada, R. Assessment of EDTA in Chromium (III-VI) Toxicity on Marine Intertidal Crab (Petrolisthes laevigatus). Bull. Environ. Contam. Toxicol. 2008, 80 (6), 526.

(35) Reish, D. J. Effects of chromium on the life history of Capitella capitata. Physiological Responses of Marine Biota to Pollutants; Vernberg, J. F., Calabrese, A., Thurberg, F. P., Vernberg, W. B., Eds.; Academic Press: London, 1981; pp 199-207.

(36) Missimer, C. L.; Lemarie, D. P.; Rue, W. J. Evaluation of a chronic estimation toxicity test using Skeletonema costatum. In Aquatic Toxicology and Hazard Assessment; ASTM International: 1989; Vol. 12, pp 345-354. 
(37) Frey, B. E.; Riedel, G. F.; Bass, A. E.; Small, L. F. Sensitivity of estuarine phytoplankton to hexavalent chromium. Estuarine, Coastal Shelf Sci. 1983, 17 (2), 181-187.

(38) Wang, Z.; Kwok, K. W.; Lui, G. C.; Zhou, G.-J.; Lee, J.-S.; Lam, M. H.; Leung, K. M. The difference between temperate and tropical saltwater species' acute sensitivity to chemicals is relatively small. Chemosphere 2014, 105, 31-43.

(39) Gissi, F.; Stauber, J. L.; Binet, M. T.; Golding, L. A.; Adams, M. S.; Schlekat, C. E.; Garman, E. R.; Jolley, D. F. A review of nickel toxicity to marine and estuarine tropical biota with particular reference to the South East Asian and Melanesian region. Environ. Pollut. 2016, 218, 1308-1323.

(40) Mackenzie, F. T.; Lerman, A. Carbon in the Oceanic Coastal Margin. In Carbon in the Geobiosphere: Earth's Outer Shell; Landman, N. H., Douglas, J. S., Eds.; Springer: Dordrecht, 2006; pp 255-288.

(41) European Union Risk Assessment Report: Nickel and Nickel Compounds; European Commission: Copenhagen, Denmark, 2008. https://echa.europa.eu/documents/10162/cefda8bc-2952-4c11-885f$342 \mathrm{aacf} 769 \mathrm{~b} 3$.

(42) Macdonald, D. D.; Carr, R. S.; Calder, F. D.; Long, E. R.; Ingersoll, C. G. Development and evaluation of sediment quality guidelines for Florida coastal waters. Ecotoxicology 1996, 5 (4), 253278.

(43) Martin, K. M.; Wood, W. T.; Becker, J. J. A global prediction of seafloor sediment porosity using machine learning. Geophys. Res. Lett. 2015, 42 (24), 10640-10646.

(44) Wang, R.-M.; Archer, C.; Bowie, A. R.; Vance, D. Zinc and nickel isotopes in seawater from the Indian Sector of the Southern Ocean: the impact of natural iron fertilization versus Southern Ocean hydrography and biogeochemistry. Chem. Geol. 2019, 511, 452-464.

(45) Danielsson, L.-G.; Magnusson, B.; Westerlund, S. Cadmium, copper, iron, nickel and zinc in the north-east Atlantic Ocean. Mar. Chem. 1985, 17 (1), 23-41.

(46) Srinivasa Reddy, M.; Basha, S.; Joshi, H.; Ramachandraiah, G. Seasonal distribution and contamination levels of total PHCs, PAHs and heavy metals in coastal waters of the Alang-Sosiya ship scrapping yard, Gulf of Cambay, India. Chemosphere 2005, 61 (11), 1587-1593.

(47) Rejomon, G.; Balachandran, K.; Nair, M.; Joseph, T. Trace metal concentrations in marine zooplankton from the western Bay of Bengal. Appl. Ecol. Environ. Res. 2008, 6 (1), 107-116.

(48) Yunus, K.; Zuraidah, M.; John, A. A review on the accumulation of heavy metals in coastal sediment of Peninsular Malaysia. Ecofeminism and Climate Change. 2020, 1 (1), 21-35.

(49) Arikibe, J. E.; Prasad, S. Determination and comparison of selected heavy metal concentrations in seawater and sediment samples in the coastal area of Suva, Fiji. Mar. Pollut. Bull. 2020, 157, 111157.

(50) Steffy, D. A.; Nichols, A. C.; Morgan, L. J.; Gibbs, R. Evidence that the Deepwater Horizon oil spill caused a change in the nickel, chromium, and lead average seasonal concentrations occurring in sea bottom sediment collected from the eastern Gulf of Mexico continental shelf between the years 2009 and 2011. Water, Air, Soil Pollut. 2013, 224 (11), 1756.

(51) Srikanth, K.; Ahmad, I.; Rao, J. V. Seasonal trend of potential toxic elements in seawater and sediments from Tuticorin coast. Water, Air, Soil Pollut. 2014, 225 (8), 2069.

(52) Partheeban, E. C.; Anbazhagan, V.; Arumugam, G.; Seshasayanan, B.; Rajendran, R.; Paray, B. A.; Al-Sadoon, M. K.; AlMfarij, A. R. Evaluation of toxic metal contaminants in the demersal flatfishes (Order: Pleuronectiformes) collected from a marine biosphere reserve. Reg. Stud. Mar. Sci. 2021, 42, 101649.

(53) Wogelius, R. A.; Walther, J. V. Olivine dissolution kinetics at near-surface conditions. Chem. Geol. 1992, 97 (1-2), 101-112.

(54) Liu, X.; Dunne, J. P.; Stock, C. A.; Harrison, M. J.; Adcroft, A.; Resplandy, L. Simulating Water Residence Time in the Coastal Ocean: A Global Perspective. Geophys. Res. Lett. 2019, 46 (23), 13910-13919.

(55) de Boyer Montégut, C.; Madec, G.; Fischer, A. S.; Lazar, A.; Iudicone, D. Mixed layer depth over the global ocean: An examination of profile data and a profile-based climatology. J. Geophys. Res. 2004, 109 (C12), C12003.

(56) Gissi, F.; Wang, Z.; Batley, G. E.; Leung, K. M.; Schlekat, C. E.; Garman, E. R.; Stauber, J. L. Deriving a chronic guideline value for nickel in tropical and temperate marine waters. Environ. Toxicol. Chem. 2020, 39 (12), 2540-2551.

(57) Hübner, R.; Astin, K. B.; Herbert, R. J. Comparison of sediment quality guidelines (SQGs) for the assessment of metal contamination in marine and estuarine environments. J. Environ. Monit. 2009, 11 (4), $713-722$.

(58) Chapman, P. M.; Allard, P. J.; Vigers, G. A. Development of sediment quality values for Hong Kong special administrative region: a possible model for other jurisdictions. Mar. Pollut. Bull. 1999, 38 (3), 161-169.

(59) Bakke, T.; Källqvist, T.; Ruus, A.; Breedveld, G. D.; Hylland, K. Development of sediment quality criteria in Norway. J. Soils Sediments 2010, 10 (2), 172-178.

(60) Birch, G. F. A review of chemical-based sediment quality assessment methodologies for the marine environment. Mar. Pollut. Bull. 2018, 133, 218-232.

(61) Frogner-Kockum, P.; Göransson, P.; Åslund, H.; Ländell, M.; Stevens, R.; Tengberg, A.; Göransson, G.; Ohlsson, Y. Metal contaminant fluxes across the sediment water interface. Mar. Pollut. Bull. 2016, 111 (1-2), 321-329.

(62) Van Cappellen, P.; Wang, Y. Metal cycling in surface sediments: modeling the interplay of transport and reaction. In Metal Contaminated Aquatic Sediments; Allen, H. E., Ed.; Ann Arbor Press, Inc.: 1995; pp 21-64.

(63) van de Velde, S.; Meysman, F. J. The influence of bioturbation on iron and sulphur cycling in marine sediments: a model analysis. Aquat. Geochem. 2016, 22 (5), 469-504.

(64) Solan, M.; Ward, E. R.; White, E. L.; Hibberd, E. E.; Cassidy, C.; Schuster, J. M.; Hale, R.; Godbold, J. A. Worldwide measurements of bioturbation intensity, ventilation rate, and the mixing depth of marine sediments. Sci. Data 2019, 6 (1), 58.

(65) Sediment Quality Assessment: A Practical Guide, 2nd ed.; Simpson, S. L., Batley, G. E., Eds.; CSIRO Publishing: Clayton, Australia, 2016

(66) Moosdorf, N.; Renforth, P.; Hartmann, J. Carbon dioxide efficiency of terrestrial enhanced weathering. Environ. Sci. Technol. 2014, 48 (9), 4809-4816.

(67) Rueda, O.; Mogollón, J.; Tukker, A.; Scherer, L. Negativeemissions technology portfolios to meet the $1.5^{\circ} \mathrm{C}$ target. Glob Environ. Change. 2021, 67, 102238.

(68) Verriopoulos, G.; Dimas, S. Combined toxicity of copper, cadmium, zinc, lead, nickel, and chrome to the copepod Tisbe holothuriae. Bull. Environ. Contam. Toxicol. 1988, 41 (3), 378-384.

(69) Adams, W. J.; Blust, R.; Borgmann, U.; Brix, K. V.; DeForest, D. K.; Green, A. S.; Meyer, J. S.; McGeer, J. C.; Paquin, P. R.; Rainbow, P. S.; Wood, C. M. Utility of tissue residues for predicting effects of metals on aquatic organisms. Integr. Environ. Assess. Manage. 2011, 7 (1), 75-98.

(70) Adams, W.; Blust, R.; Dwyer, R.; Mount, D.; Nordheim, E.; Rodriguez, P. H.; Spry, D. Bioavailability assessment of metals in freshwater environments: A historical review. Environ. Toxicol. Chem. 2020, 39 (1), 48-59.

(71) Peters, A.; Merrington, G.; Schlekat, C.; De Schamphelaere, K.; Stauber, J.; Batley, G.; Harford, A.; Van Dam, R.; Pease, C.; Mooney, T.; et al. Validation of the nickel biotic ligand model for locally relevant species in Australian freshwaters. Environ. Toxicol. Chem. 2018, 37 (10), 2566-2574.

(72) Stauber, J.; Golding, L.; Peters, A.; Merrington, G.; Adams, M.; Binet, M.; Batley, G.; Gissi, F.; McKnight, K.; Garman, E.; et al. Application of Bioavailability Models to Derive Chronic Guideline Values for Nickel in Freshwaters of Australia and New Zealand. Environ. Toxicol. Chem. 2021, 40 (1), 100-112.

(73) Sherman, S.; Chen, W.; Blewett, T.; Smith, S.; Middleton, E.; Garman, E.; Schlekat, C.; McGeer, J. Complexation reduces nickel toxicity to purple sea urchin embryos (Strongylocentrotus purpur- 
atus), a test of biotic ligand principles in seawater. Ecotoxicol. Environ. Saf. 2021, 216, 112156. 